\title{
Production and Characterization of a Nitrilase from Pseudomonas aeruginosa RZ44 and its Potential for Nitrile Biotransformation
}

\author{
Arastoo Badoei-Dalfard *, Narjes Ramezani-pour, Zahra Karami \\ Department of Biology, Faculty of Sciences, Shahid Bahonar University of Kerman, Kerman, Iran \\ ${ }^{*}$ Corresponding author: Arastoo Badoei-Dalfard, Department of Biology, Faculty of Sciences, Shahid Bahonar University of Kerman, Kerman, Iran. \\ Tel: +98-3431322044; Fax: +98-3431322060; E-mail: badoei@uk.ac.ir
}

Received: March 12, 2015; Revised: October 29, 2015; Accepted: March 05, 2016

\begin{abstract}
Background: The conversion of nitriles into amides or carboxylic acids by nitrilase has taken its application into consideration, as the scope of its applications has recently been extended.

Objectives: In this study, P. aeruginosa RZ44 was isolated from sewage in the Kerman which has Nitrile-degradation activity. In order to improve the nitrilase production, several optimization were done on environmental condition. Nitrilase activity was characterized against different $\mathrm{pHs}$, temperatures, ions, and substrates.

Materials and Methods: Enzyme activity was evaluated by determining the production of ammonia following to the modification of the phenol/hypochlorite method. Different factors that affect production of the enzyme by P. aeruginosa RZ44 were optimized and evaluated in the culture mediums.

Results: The results showed that degradation of the acetonitrile by P. aeruginosa RZ44 increased the $\mathrm{pH}$ of the growth medium from the initial $\mathrm{pH} 7.0$ to 9.37. Optimizing the medium for $P$. aeruginosa RZ44, it was found that glucose and starch $\left(5\right.$ g.L.-1) have strongly supported nitrilase production, compared to the control. As well, urea $\left(5\right.$ g.L $\left.\mathrm{L}^{-1}\right)$ and yeast extract $\left(15\right.$ g.L $\left.\mathrm{L}^{-1}\right)$ have favored an increased biomass and nitrilase production, as the nitrogen sources. These results show that nitrilase production increases in the $\mathrm{pH}$ range 5.0 to 7.0 and then start decreasing. Addition of the $\mathrm{Mg}^{2+}, \mathrm{Fe}^{2+}$ and $\mathrm{Na}^{+}$ has supported the biomass and nitrilase production. $\mathrm{Co}^{2+}, \mathrm{Mn}^{2+}$ and $\mathrm{Cu}^{2+}$ were confirmed to inhibit cell growth and enzyme production. Enzyme characterization results show that, $P$. aeruginosa RZ44 nitrilase exhibits comparatively high activity and stability at $\mathrm{pH} 7.0$ and $40^{\circ} \mathrm{C}$. Nitrilase was completely inhibited by $\mathrm{CoCl}_{2}$ and $\mathrm{CaCl}_{2}$, whereas, the inhibition in the presence of $\mathrm{MnSO}_{4}$ and $\mathrm{CuSO}_{4}$ was about $60 \%$. Time course analysis of the nitrile conversion by the resting $P$. aeruginosa RZ44 cells showed that nitrile substrates (i.e. acetonitrile) was hydrolyzed within $8 \mathrm{~h}$.

Conclusions: these results indicate that $P$. aeruginosa RZ44 has the potential to be applied in the biotransformation of nitrile compounds.

Keywords: Nitrilase; Nitrile; Nitrile-degrading bacteria; Production; Pseudomonas aeruginosa; Sewage
\end{abstract}

\section{Background}

Nitriles are broadly used in the organic synthesis of the amides, carboxylic acids, and their derivatives (16). In addition, these compounds are presumed to have an abundant impact in the chemical industrial procedures, where they are primarily used for the production of the numerous fine chemicals (1), in the ecological sciences, as the carcinogenic compounds, neurotoxic, as well as ecological contaminants (7). Chemical hydrolysis of the nitriles often includes fairly severe situations that impede the use of nitriles carrying sensitive functionalities. Furthermore, the undesirable byproducts, including large amount of salt, are regularly produce (8). Biotransformation of the nitriles by nitrile hydrolyzing enzymes $(1,9)$, overcomes these problems and may deal with an extra benefit of the stereospecificity (10-13). The use of nitrile-degrading enzymes has expanded its abundant interest among scientists for the conversion of the nitriles to the valuable chemical products (14), or reclamation of the nitrile polluted soil/water $(15,16)$. To these interest it could be added the production of the commercially feasible compounds, such as acrylamide (17), antibiotics, anti-inflammatory agents (18), as well as herbicides $(10,19)$. Microbial degradation has been investigated as an effective approach for eliminating the highly poisonous nitriles from the environment. Some of the recently reported nitrle-hydrolyzing bacteria 
include: Alcaligenes sp. $(3,8)$, Arthrobacter nitroguajacolicus (14), Nocardia globerula NHN-2 (20), Serratia marcescens (21), Pseudomonas (4, 13, 22, 23), Geobacillus pallidus (24), Rhodococcus rhodochrous PA-34 (25), and Isoptericola variabilis RGT01 (26). In spite of this notion, there are only few reports about optimization of the different factors for the maximum production of nitrilases.

\section{Objectives}

In this study, P. aeruginosa RZ44 was isolated from sewage in the Kerman which has Nitrile-degradation activity. In order to improve the nitrilase production from Pseudomonas aeruginosa RZ44, several optimization were done on environmental condition. Nitrilase activity was biochemically characterized against different $\mathrm{pHs}$, temperatures, ions, and substrates.

\section{Material and Methods}

\subsection{Chemicals}

All substrates were procured from Merck (White house Station, New Jersey, United States). The culture media ingredients were from Sigma (St. Louis, MO, USA). All the other chemicals were of analytical grade and purchased from various suppliers.

\subsection{Screening of the Acetonitrile-Degrading Bacteria}

Soil and water samples were picked up from the sewage of the Kerman city, Iran. Nitrile-degrading bacteria were screened through application of the enrichment culture and indicator plate methods. Cultures were grown in the mineral salts medium (MM1), which was lacking for carbon and nitrogen source and contained the following components (\%): $\mathrm{K}_{2} \mathrm{HPO}_{4} 0.68 ; \mathrm{KH}_{2} \mathrm{PO}_{4} 0.12 ; \mathrm{MgSO}_{4} .7 \mathrm{H}_{2} \mathrm{O} 0.01$; $\mathrm{MnSO}_{4} \cdot 4 \mathrm{H}_{2} \mathrm{O} 0.01 ; \mathrm{CaCl}_{2} \cdot 2 \mathrm{H}_{2} \mathrm{O} \quad 0.01 ; \mathrm{FeSO}_{4} \cdot 7 \mathrm{H}_{2} \mathrm{O}$ $0.01 ; \mathrm{Na}_{2} \mathrm{MoO}_{7} .2 \mathrm{H}_{2} \mathrm{O} 0.0006$ (27). The $\mathrm{pH}$ of the medium was adjusted to 7.0 and autoclaving at $121^{\circ} \mathrm{C}$ was done for $15 \mathrm{~min}$. The bacteria were propagated using MM1 medium complemented with $1 \%$ filtered sterile acetonitrile $(0.4 \mathrm{M})$ as the sole source of nitrogen, carbon, and energy. The flasks were inoculated and incubated at $30^{\circ} \mathrm{C}$ in an orbital shaker at $168 \mathrm{rpm}$. Indicator plates were prepared from a MM1 medium with phenol red $(0.015 \%(\mathrm{w} / \mathrm{v}))$ and $1.5 \%$ agar, overlaid with $100 \mu \mathrm{L}$ nitriles.

\subsection{Identification of the Acetonitrile-Degrading Bacteria}

The $P$. aeruginosa RZ44 was identified by using the 16S rRNA gene sequencing method. The DNA of the bacteria was extracted according to the Sambrook and Russell (28). The 16S ribosomal genes were amplified from the bacterial total genomic DNA by using polymerase chain reaction (PCR). Universal 16S rRNA forward primer ( $5^{\prime}$-AGTTTGATCCTGGCTCAG$\left.3^{\prime}\right)$ and the reverse primer (5'-GGCACCTTGTTACGACTT-3') were used for the PCR amplification of the 16S rRNA gene (29). Each $200 \mu \mathrm{L}$ microtube contained $2 \mu \mathrm{L}$ of the purified extracted DNA; $1.5 \mu \mathrm{L}$ of dNTP at $2.5 \mathrm{mM} ; 2.5 \mu \mathrm{L}$ of $10 \mathrm{X}$ buffer; $0.2 \mu \mathrm{L}$ of 2.5 unit Taq DNA polymerase; $16.8 \mu \mathrm{L}$ of the sterile water and $1 \mu \mathrm{L}$ of the primers (final concentration: $10 \mathrm{pmol}$ ). PCR was performed in a Biorad PCR system thermal cycler with a hot starting of the reaction performed at $95^{\circ} \mathrm{C}$ for $5 \mathrm{~min}$, followed by 33 cycles of $94^{\circ} \mathrm{C}$ for 1 $\mathrm{min}, 54^{\circ} \mathrm{C}$ for $0.45 \mathrm{~min}$, and $72^{\circ} \mathrm{C}$ for $1 \mathrm{~min}$, followed by a final extension at $72^{\circ} \mathrm{C}$ for $10 \mathrm{~min}$. PCR products were electrophoresed on agarose gel (1\%), and subsequently the amplified 16S rRNA bands were purified by applying DNA extraction kit (Cinaclone, Iran). DNA sequencing was performed on both strands directly by SEQ-LAB (Germany).

The phylogenetic tree was constructed based on the comparison between 16S rRNA sequences obtained for $P$. aeruginosa RZ44 with those other strains of Pseudomonas species that were obtained from GenBank database (http://www.ncbi.nlm.nih.gov). All sequences were aligned applying Clustal Omega (http://www.seqtool.sdsc.edu/CGI/Omega.cgi) and the phylogenetic tree was constructed in MEGA4 (30). The obtained 16S rRNA sequence was deposited in GenBank for isolate $P$. aeruginosa RZ44, with KM229744 accession number.

\subsection{Nitrilase Purification}

The pellet was gathered by centrifugation at $8000 \mathrm{~g}$ for $10 \mathrm{~min}$, subsequently washed with $0.05 \mathrm{M}$ sodium phosphate buffer having $1 \mathrm{mM}$ dithiothreitol and $20 \%$ $(\mathrm{v} / \mathrm{v})$ glycerol ( $\mathrm{pH} 7.5)$, and re-centrifuged for $20 \mathrm{~min}$ at $13000 \mathrm{rpm}$. The pellet was then suspended in a minimal volume of $0.05 \mathrm{M}$ sodium phosphate buffer $(\mathrm{pH}$ 7.5) (19). Cell were suspended and then disrupted by sonication on ice $(5 \mathrm{~min}, 35 \mathrm{kHz}$, sonicator, hielscher, Germany). The disrupted cells were centrifuged at $13000 \mathrm{rpm}$ for $20 \mathrm{~min}$ and supernatant was collected. The supernatant was fractionated stepwise through precipitation with the ammonium sulfate powder at different saturation. The precipitate formed in each step was collected by centrifugation at $12000 \mathrm{rpm}$ for $20 \mathrm{~min}$, dissolved in $1 \mathrm{~mL} 50 \mathrm{mM}$ potassium phosphate buffer and assayed for enzyme activity. The frac- 
tion with the highest nitrilase activity was dialyzed overnight against Tris/ $\mathrm{HCl}$ buffer $(\mathrm{pH} 7.5)$ to remove the remaining salt. The desalted samples were directly loaded onto a Q-sepharose $(1.5 \times 24 \mathrm{~cm})$ previously equilibrated with $45 \mathrm{mM}$ potassium phosphate buffer ( $\mathrm{pH}$ 7.2) and the column was eluted with a linear gradient of $0-1.0 \mathrm{M} \mathrm{NaCl}$ at a flow rate of $1 \mathrm{~mL} \cdot \mathrm{min}^{-1}$. The nitrilase activity in the eluted fractions was determined, and the active fraction from the previous step was further purified by gel filtration using Sephadex G-100 $(1 \times 100 \mathrm{~cm})$. The fractions showing nitrilase activity were pooled and used as RZ44 nitrilase for the following studies. The nitrilase purity was checked with SDS-PAGE (10\% gel) under reducing conditions.

\subsection{Acetonitrile-Degrading Enzyme Assay}

Enzyme activity was evaluated by determining the production of ammonia following to the modification of the phenol/hypochlorite method (31). The following components were used for ammonia detection. Reagent A contained 0.6 M phenol and $0.001 \mathrm{M}$ sodium nitroprusside. Reagent B contained $0.11 \mathrm{M}$ sodium hypochlorite and 2.1 M sodium hydroxide (19). The standard assay was done in duplicate at $37^{\circ} \mathrm{C}$ in a reaction containing $180 \mu \mathrm{L}$ potassium phosphate buffer $(0.1 \mathrm{M}, \mathrm{pH} 7.5), 20 \mu \mathrm{L}$ enzyme, $100 \mu \mathrm{L}$ of the $150 \mathrm{mM}$ acetonitrile or $1.2 \mathrm{M}$ acetamide. Samples were incubated at $37^{\circ} \mathrm{C}$ for $20 \mathrm{~min}$. The reaction was quenched by addition of $100 \mu \mathrm{L}$ of the assay mixture to $300 \mu \mathrm{L}$ reagent $B$ followed by rapid addition of $300 \mu \mathrm{L}$ reagent $A$ with vigorous mixing and incubation at $45^{\circ} \mathrm{C}$ for $20 \mathrm{~min}$. The absorbance was then measured in a spectrophotometer (Biochrom WPA Biowave II). One unit of nitrile degrading enzyme activity was defined as the amount of enzyme capable of releasing $1 \mu \mathrm{mol}$ ammonia.min ${ }^{-1}$ under standard reaction situations $(\mathrm{pH}$ $7.5,45^{\circ} \mathrm{C}, 50 \mathrm{mM}$ acetonitrile as substrate) (19).

\subsection{Effect of the Culture Conditions on the Enzyme Production}

Different factors that affect production of the enzyme by $P$. aeruginosa RZ44 were optimized and evaluated in the culture mediums with a different $\mathrm{pH}$ (i. e. 5.0, 6.0, 7.0, and 8.0). Several carbon sources were used including: glucose, mannitol, acetate, citrate, glycerol, sucrose, fructose, starch, and maltose with the same concentration as subsequently were inoculated with the $P$. aeruginosa RZ44. As well, several nitrogen sources including: yeast extract, peptone, urea, sodium nitrate, and Triton X-100, all at the same concentration were also considered and were inoculated with the $P$. aeruginosa RZ44. In addition, several ion sources were also studied, including: $\mathrm{ZnSO}_{4}$, $\mathrm{CuSO}_{4}, \mathrm{MnSO}_{4}, \mathrm{MgSO}_{4}, \mathrm{FeSO}_{4}, \mathrm{CoCl}_{2}, \mathrm{CaCl}_{2}$, and $\mathrm{NaCl}$ with the same amount that was followed by inoculation of the P. aeruginosa RZ44 in the medium supplied with the ion source under study $(21,32-34)$.

\subsection{Enzyme Characterization}

\subsubsection{Effect of $p H$ and Temperature on Enzyme Activity and Stability}

The effect of $\mathrm{pH}$ and temperature on nitrilase RZ44 was considered by incubating the enzyme with substrate in buffers of diverse $\mathrm{pHs}$ (pHs from 4 to-10) or at diverse temperatures (from 30 to $90^{\circ} \mathrm{C}$ ). The optimum $\mathrm{pH}$ for the enzyme was considered by using the sodium acetate ( $\mathrm{pH} 4-6)$, phosphate (6-8), and Tris$\mathrm{HCl}(8-10)$ buffers. The enzyme was incubated in $1 \mathrm{~mL}$ of the respective buffer with substrate $(10 \mathrm{mM})$ in a reaction microtube at room temperature $(21,35)$. For determination of the optimum temperature, the enzyme was incubated in $1 \mathrm{~mL}$ of potassium phosphate buffer $(50 \mathrm{mM}, \mathrm{pH} 7.0)$ with substrate $(10 \mathrm{mM})$ in a reaction vial at 30 to $90^{\circ} \mathrm{C}$. The reactions stopped after $20 \mathrm{~min}$ by addition of $10 \mu \mathrm{L}$ of $2 \mathrm{M} \mathrm{HCl} \mathrm{(23).}$

\subsubsection{Effect of Metal Ions and other Chemicals}

To study the effect of metal ions on the enzyme activity, the enzyme was assessed under standard condition and in the presence of different metal ions $\left(\mathrm{CaCl}_{2}, \mathrm{CoCl}_{2}, \mathrm{ZnCl}_{2}, \mathrm{FeSO}_{4}, \mathrm{CuSO}_{4}, \mathrm{MgSO}_{4}\right.$, $\mathrm{MnSO}_{4}, \mathrm{ZnSO}_{4}$, DTT, EDTA, and $\mathrm{HgCl}_{2}$ ) supplemented with potassium phosphate buffer $(0.1 \mathrm{M}, \mathrm{pH} 7.5)$ and chemicals with a final concentration of $1 \mathrm{mM}(23$, $36)$. Acetonitrile $(10 \mathrm{mM})$ was used as the substrate and the enzyme activity was measured as described above. The measured activities were compared with the activity of the enzyme under the same condition in a mixture without addition of any ion.

\subsubsection{Determination of Kinetic Parameters}

The specific activity of the crude enzyme toward acetonitrile and acetamide was investigated by quantification of the amount of ammonia released during hydrolysis. The standard reaction mixture $(400 \mu \mathrm{L})$ was composed of $50 \mathrm{mM}$ potassium phosphate buffer $(\mathrm{pH}$ 7.0), $10 \mathrm{mM}$ of substrate, $10 \mu \mathrm{L}$ of methanol, and an appropriate amount of the enzyme. Initial velocities at $\mathrm{pH} 7.0$ were determined for enzyme by calculating the initial rate of substrate hydrolysis in the range of $1 \mathrm{mM}$ to $60 \mathrm{mM}$. $K_{\mathrm{m}}$ and $V_{\max }$ values were determined from Lineweaver-Burk plots using standard linear regression methods. 
3.7.4. The Substrate Activity Profile of RZ44 Nitrilase

The RZ44 nitrilase was incubated for $30 \mathrm{~min}$ in 300 $\mu \mathrm{L}$ of the sodium phosphate buffer $(\mathrm{pH} 7.0,50 \mathrm{mM})$ plus $5 \%(\mathrm{v} / \mathrm{v})$ methanol, and $10 \mathrm{mM}$ concentration of the respective nitriles. A range of nitrile compounds were used as substrates including saturated nitrileamide (acetonitrile and acetamide), unsaturated nitrileamide (acrylonitrile and acrylamide), cyclic nitrileamide (3-cyanopyridine), aromatic nitrile (benzonitrile, benzoamide, 2-amino benzonitrile) and different amide substrates (23). The reaction was stopped by the addition of $10 \mu \mathrm{L}$ of $\mathrm{HCl}(2.0 \mathrm{M})$ and the precipitated protein was removed by centrifugation in a Helmer centrifuge $(12,000 \times \mathrm{g}, 5 \mathrm{~min})$. The amount of ammonia in the supernatant was measured as described above.

\subsubsection{Biotransformation}

$P$. aeruginosa RZ44 cells were cultivated in 250$\mathrm{mL}$ Erlenmeyer flasks containing $50 \mathrm{~mL}$ of the optimized medium (glucose 10 g.L $L^{-1}$, yeast extract 5 g.L $L^{-1}$, $\mathrm{KH}_{2} \mathrm{PO}_{4} 2$ g.L ${ }^{-1}, \mathrm{NaCl} 1$ g.L.-1, $\mathrm{MgSO}_{4} 0.2$ g.L ${ }^{-1}$, nitrile $20 \mathrm{mM}, \mathrm{pH} 7.0)$ at $30^{\circ} \mathrm{C}$ in rotating shaker $(168 \mathrm{rpm})$. After $48 \mathrm{~h}$, cells were centrifuged and suspended in $100 \mathrm{mM}$ phosphate buffer ( $\mathrm{pH} 7.5)$. The reaction, consisting of the nitrile (at final concentrations of $20 \mathrm{mM}$ ) and $20 \mathrm{mg}$ (wet weight) of resting cells in $10 \mathrm{~mL}$ phosphate buffer $(\mathrm{pH} 6.5,100 \mathrm{mM})$, was carried out at $30^{\circ} \mathrm{C}$ and $168 \mathrm{rpm}$. Samples $(100 \mu \mathrm{L}$ each) from the reaction mixture were taken at regular intervals, and cells were removed by centrifugation $(21,37,38)$. The amount of the produce ammonia was measured as described above and an analytical method was done as follows. The amount of nitrile, amide, and acid were also determined by gas chromatography (GC, CP3800, Varian, United States) using CP8740 column (30 $\mathrm{M}, 0.32 \mathrm{~mm}, 0.1 \mu \mathrm{m}$ ) equipped with a flame ionization detector (FID). The column, injector and detector temperatures were set at 180,230 and $250^{\circ} \mathrm{C}$, respectively. The flow of helium was maintained at $30 \mathrm{~mL} \cdot \mathrm{min}^{-1}$. Five $\mu \mathrm{L}$ of the reaction mixture was injected and the residual substrate concentration was calculated against the standard curve $(32,38,39)$.

\section{Results}

\subsection{Screening of the Nitrile-Degrading Bacteria}

Water/soil samples were collected from the sewage sites in the Kerman city (southeastern, Iran), and were stored at $-20^{\circ} \mathrm{C}$. The primary isolations was done by inoculation of these samples on the minimal nutrient media (MM1) containing 1\% acetonitrile as the sole carbon source. After incubation at $30^{\circ} \mathrm{C}$ for 5 days, samples were picked up and inoculated into flasks containing fresh medium. Subsequently, flasks were incubated for 3 days at $30^{\circ} \mathrm{C}$. After that, the samples were picked up and streaked on the minimal nutrient plates containing phenol red as a $\mathrm{pH}$ indicator. As well, plates were overlaid with $100 \mu \mathrm{L}$ acetonitrile before streaking and then incubated in the $30^{\circ} \mathrm{C}$ for 3 days. 13 isolates were examined for their ability to change the color of medium from yellow to pink, which was an indicator of the ammonia production from acetonitrile. A single strain (designated as RZ44) which showed a higher pink halo around the bacterial growth zone in the minimal nutrient medium plate compared to the other isolates was selected for further characterization. The $\mathrm{pH}$ of the medium and production of ammonia by acetonitrile are shown in (Figure 1). These results indicate that degradation of acetonitrile by $P$. aeruginosa strain RZ44 increases the $\mathrm{pH}$ of the growth medium from initial $\mathrm{pH} 7.0$ to 9.37 .

\subsection{Biochemical and Molecular Characterization}

The physiological characteristics of the RZ44 strain were also investigated. Strain RZ44 was a Gram negative, non-spore forming bacterium. Catalase and oxidase reactions were positive, as well as liquefaction of gelatin, nitrate reduction, in addition to hydrolysis of the casein. Starch hydrolysis, Voges-Proskauer test, methyl red test, urease, indole and $\mathrm{H}_{2} \mathrm{~S}$ production were negative (40). These data indicated that strain

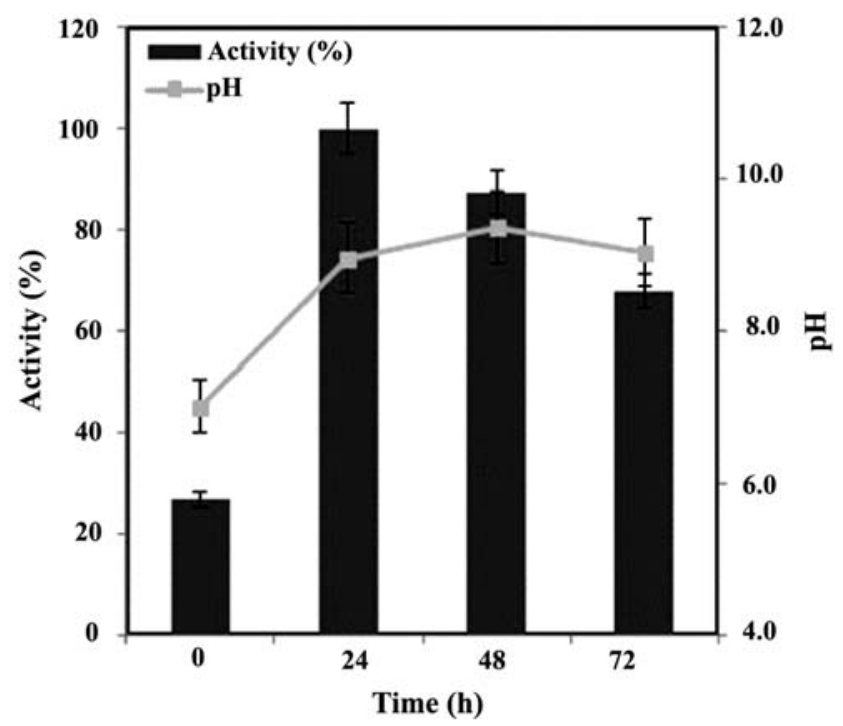

Figure 1. $\mathrm{pH}$ of the growth medium and concentration of ammonia liberated from acetonitrile degradation. Pseudomonas aeruginosa RZ44 was cultured and samples picked up at $24 \mathrm{~h}$ intervals. All experimental data are means \pm standard deviation (SD) of triplicate determinations 


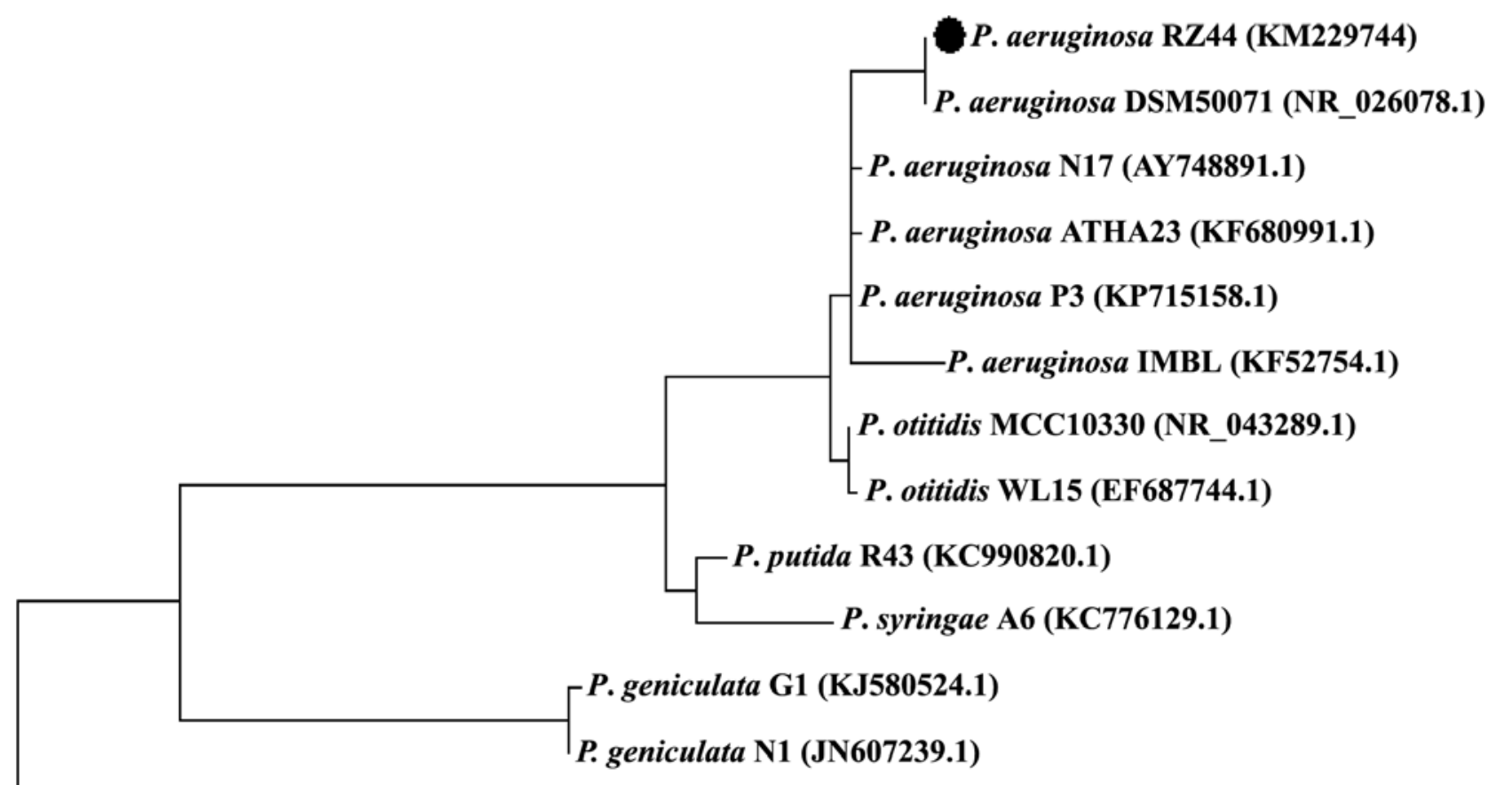

Microbacterium agarici (FJ807673.1)

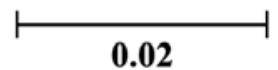

Figure 2. The phylogenetic dendrogram constructed for Pseudomonas aeruginosa RZ44 and related strains based on the 16S rRNA sequence. Microbacterium agarici was used as a outgroup

RZ44 resembles to a member of Pseudomonas genus. Strain RZ44 was 100\% identical in the sequence with Pseudomonas aeruginosa by examining phylogenetic tree (Figure 2) according to the 16S rRNA sequence. The sequence was deposited in the GenBank database with accession no. KM229744.

\subsection{Investigation of the Medium Optimization}

The strain RZ44 was grown in different carbon sources $\left(10\right.$ g. $\left.\mathrm{L}^{-1}\right)$ in order to observe the activity pattern of the nitrilase. As the results shown in (Table 1), glycerol slightly decreased nitrilase production, while glucose and starch strongly supported the nitrilase pro-

Table 1. The effect of different carbon and ion sources on the bacterial growth and nitrilase production of $P$. aeruginosa RZ44

\begin{tabular}{lccccc}
\hline Carbon sources & Activity (\%) & $\begin{array}{c}\text { Biomass } \\
\text { (mg.mL-1) }\end{array}$ & $\begin{array}{c}\text { lon } \\
\text { sources }\end{array}$ & Activity (\%) & $\begin{array}{c}\text { Biomass } \\
\text { (mg.mL-1) }\end{array}$ \\
\hline Control & 100 & 9.6 & Control & 100 & 14.0 \\
Glucose & $820 \pm 2.1$ & 80.0 & $\mathrm{ZnSO}$ & $94.0 \pm 1.2$ & 12.0 \\
Fructose & $159 \pm 3.2$ & 15.0 & $\mathrm{MnSO}_{4}$ & $82.0 \pm 1.3$ & 8.0 \\
Manitol & $180 \pm 2.1$ & 5.0 & $\mathrm{MgSO}_{4}$ & $142.0 \pm 1.3$ & 30.0 \\
Maltose & $404 \pm 1.6$ & 22.0 & $\mathrm{FeSO}_{4}$ & $130 \pm 1.2$ & 35.0 \\
Sucrose & $123 \pm 1.6$ & 20.0 & $\mathrm{CuSO}_{4}$ & $70 \pm 2.2$ & 9.30 \\
Starch & $550 \pm 1.3$ & 22.0 & $\mathrm{CaCl}_{2}$ & $87 \pm 2.1$ & 14.8 \\
Acetate & $225 \pm 2.2$ & 21.0 & $\mathrm{CoCl}_{2}$ & $80 \pm 1.6$ & 16.4 \\
Citrate & $360 \pm 3.1$ & 22.0 & $\mathrm{NaCl}^{2}$ & $170 \pm 2.6$ & 40.0 \\
Glycerol & $73 \pm 2.1$ & 8.2 & & & \\
\hline
\end{tabular}


A

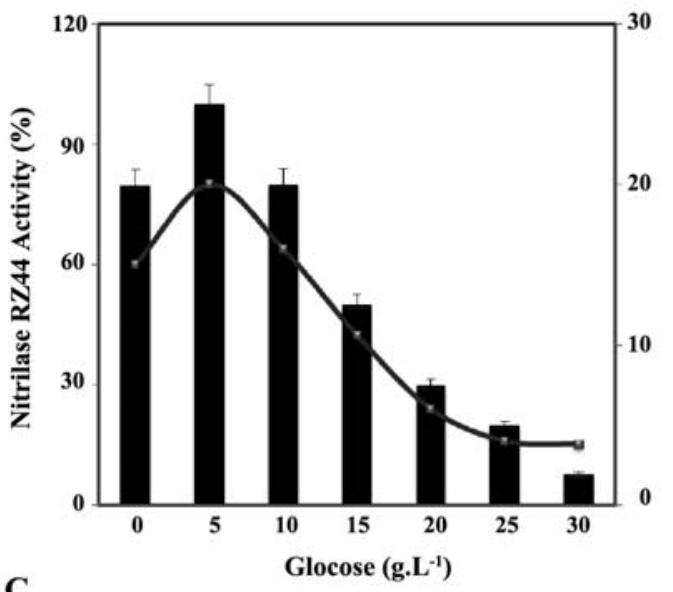

C

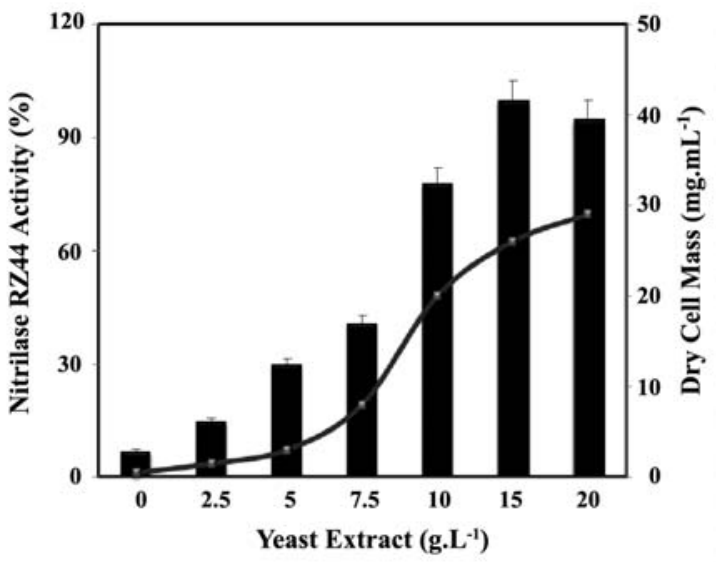

B

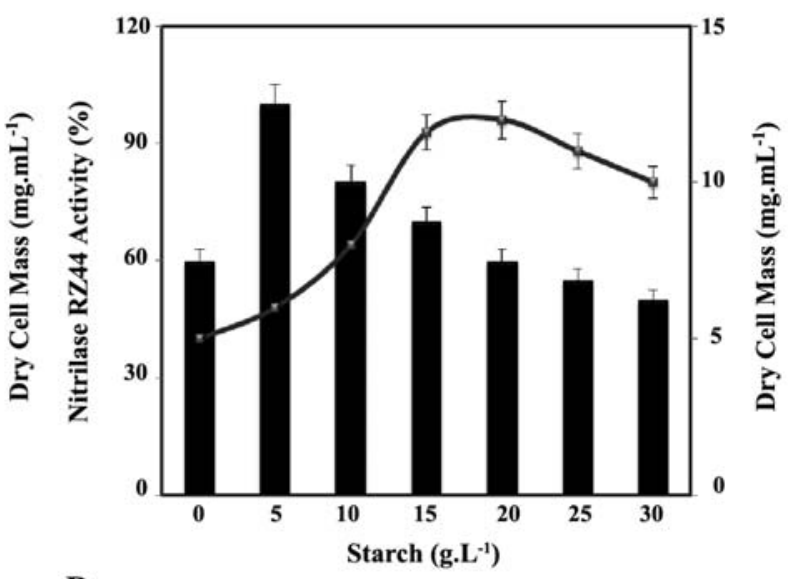

D

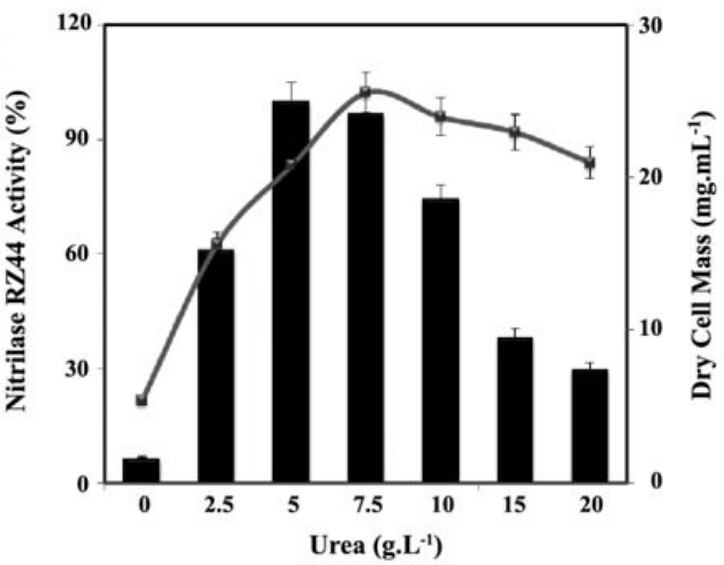

Figure 3. Effects of different concentratios of the A: glucose, B: starch, C: yeast extract, and D: urea on the bacterial growth and nitrilase production of $P$. aeruginosa RZ44. Enzyme production was measeured after $48 \mathrm{~h}$ incubation of $P$. aeruginosa RZ44. All experimental data are means \pm standard deviation (SD) of triplicate determinations

duction, compared to the control. Furthermore, in the present study, we have also investigated the effect of different concentration of glucose and starch to find the best concentration of these components for nitrilase and biomass production. In these experiments,

Table 2. The effect of different nitrogen sources and different $\mathrm{pHs}$ on the bacterial growth and nitrilase production of $P$. aeruginosa RZ44

\begin{tabular}{lccccc}
\hline $\begin{array}{l}\text { Nitrogen } \\
\text { sources }\end{array}$ & $\begin{array}{c}\text { Activity } \\
(\%)\end{array}$ & $\begin{array}{c}\text { Biomass } \\
\left(\mathbf{m g} \cdot \mathbf{m L}^{-1}\right)\end{array}$ & $\begin{array}{c}\text { pH } \\
\text { Activity } \\
(\%)\end{array}$ & $\begin{array}{c}\text { Biomass } \\
\left(\mathbf{m g} \cdot \mathbf{m L}^{-1}\right)\end{array}$ \\
\hline Control & 100 & 5.7 & 5.0 & $80.0 \pm 2.5$ & 52 \\
Yeast extract & $650 \pm 2.1$ & 7.0 & 6.0 & $92.0 \pm 2.1$ & 60 \\
pepton & $400 \pm 3.2$ & 4.1 & 7.0 & $100 \pm 1.9$ & 65 \\
$\mathrm{~T} X 100$ & $140 \pm 2.1$ & 4.3 & 8.0 & $90 \pm 1.8$ & 60 \\
Urea & $780 \pm 1.6$ & 11.3 & & & \\
$\mathrm{NaNO}_{3}$ & $120 \pm 1.7$ & 8.4 & & & \\
\hline
\end{tabular}

other media components and physiological parameters were kept constant, and the activity was analyzed after $48 \mathrm{~h}$ of growth. The results in (Figure 3 ) indicate that 5 g.L $\mathrm{L}^{-1}$ glucose and starch is the optimal concentration of the nitrilase production.

As one of the major components of the culture medium, the effects of various nitrogen sources $\left(5 \mathrm{~g} . \mathrm{L}^{-1}\right)$ was also investigated in this study (Table 2). As shown in Table 2, the lowest biomass and nitrilase production could be detected when sodium nitrate and Triton X-100 are used as the nitrogen sources, in contrast, urea and yeast extract favor the more biomass and nitrilase production. The mentioned factors were selected as the suitable nitrogen sources for further study. Results in figure3 show that the 15 g.L-1 yeast extract and 5 g.L.-1 urea are the optimum concentration for the nitrilase production.

The effect of the $\mathrm{pH}$ on P. aeruginosa RZ44 nitrilase production was examined by changing the $\mathrm{pH}$ of the pro- 
duction medium in a range from 5.0 to 8.0 and allowing the culture to grow for $48 \mathrm{~h}$ at $30^{\circ} \mathrm{C}$. The speed of the shaker was adjusted to $168 \mathrm{rpm}$. Nitrilase activity at the different $\mathrm{pH}$ of the medium was assessed and are summarized in Table 2. These results show that nitrilase activity increases in a range of $\mathrm{pH}$ from 5.0 to 7.0; then it starts to decrease. The optimum $\mathrm{pH}$ for nitrilase production is 7.0, therefore, in subsequent studies, the $\mathrm{pH}$ of the medium was adjusted to 7.0 before sterilization.

In this study, the effects of various metal ions $(0.2$ g. $\left.\mathrm{L}^{-1}\right)$ on biomass and nitrilase production was also investigated. The medium without metal ion was considered as the control, while the other ingredients were kept unchanged. As shown in Table 1, the addition of $\mathrm{Mg}^{2+}, \mathrm{Fe}^{2+}$, and $\mathrm{Na}^{+}$support the biomass and nitrilase production.

\subsection{Enzyme Characterization}

The apparent molecular mass of the purified RZ44 nitrilase as obtained by SDS-PAGE is about $30 \mathrm{kDa}$ (Figure 4). The molecular weights of nitrilase from other bacterial species have been reported as $45 \mathrm{kDa}$ for Bacillus cereus strain FA12 (41), $43 \mathrm{kDa}$ for Pseudomonas putida (42), and $33 \mathrm{kDa}$ for P. fluorescens Pf5 (23).

\subsubsection{Effect of $p H$ on the Enzyme Activity and Stability}

To investigate the effect of $\mathrm{pH}$ on the enzyme activity and stability, buffers including Na-acetate $(\mathrm{pH} 4.0-$ 6.0), phosphate ( $\mathrm{pH} 6.0-8.0)$, and Tris- $\mathrm{HCl}(\mathrm{pH} 7.0-$ 10.0 ), with a concentrations of $50 \mathrm{mM}$ for each were

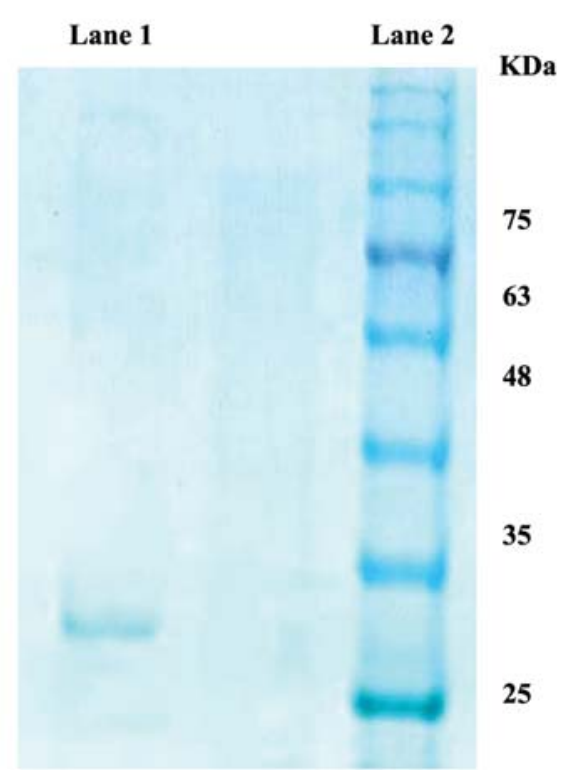

Figure 4. SDS-PAGE assessment of the purified nitrilase RZ44 (Lane 1) and the protein molecular weight markers (Lane 2)
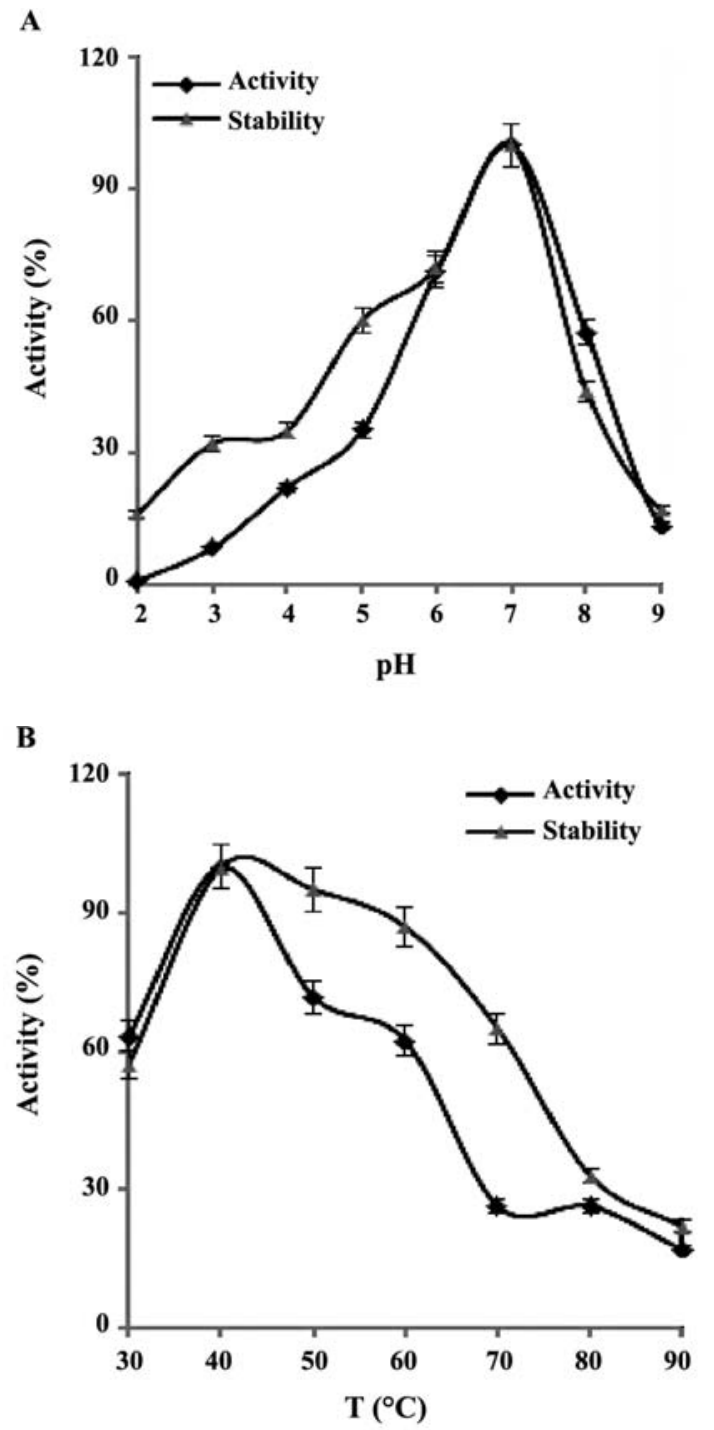

Figure 5. The effect of A: pHs (2.0-9.0) and B: temperatures (T) $\left(30-90^{\circ} \mathrm{C}\right)$ on the relative nitrilase activity and stability. Enzyme activity was evaluated by determining the production of ammonia following to the modification of the phenol/hypochlorite method as described in the material and methods section. All experimental data are means \pm standard deviation (SD) of triplicate determinations

used. According to the standard method described above, the relative residual activity was measured for the $\mathrm{pH}$ stability assessment. The enzyme shows the highest activity and stability comparatively at $\mathrm{pH}$ 7.0, as it drastically is lost in the low and the high $\mathrm{pH}$. The enzyme retained more than $50 \%$ activity at $\mathrm{pH} 6.0$ and 8.0 (Figure 5).

\subsubsection{Effect of Temperature on the Enzyme Activity and Stability}

Since the temperature is the key factor for reaction rate, the effect of temperature on the nitrilase activity 
was investigated at various temperatures $\left(30-90^{\circ} \mathrm{C}\right)$. The results showed that the optimum temperature for the nitrilase activity and stability is $40^{\circ} \mathrm{C}$, which then gradually subjects to the reduction. Enzyme activity was about $60 \%$ at $60^{\circ} \mathrm{C}$ (Figure 5). It is well known that thermostability is an index of a significant importance for the nitrilase. In this study, the thermostability of the nitrilase was found to be comparatively acceptable under $60^{\circ} \mathrm{C}$. According to the figure 5, thermostability of the RZ44 nitrilase was about $85 \%$ of the initial thermostability at $60^{\circ} \mathrm{C}$.

\subsubsection{Effect of Metal Ions and Chemicals on Enzyme Activity}

The effects of various metal ions and reagents on the enzyme activity was investigated. The enzyme was assayed under standard condition with $1 \mathrm{mM}$ concentrations of the various reagents. RZ44 nitrilase was entirely repressed by $\mathrm{Co}^{+2}$ and $\mathrm{Ca}^{+2}$, while it was inhibited almost $60 \%$ in the presence of $\mathrm{MnSO}_{4}$ and $\mathrm{CuSO}_{4}$. The enzyme activity was slightly increased in the presence of $\mathrm{Fe}^{+2}$ and $\mathrm{Mg}^{+2}$ (Table 3).

\subsubsection{Substrate Specificity and Biotransformation}

The Michaelis-Menten constant $(\mathrm{Km})$ of the nitrilase RZ44 for acetonitrile and acetamide was determined by varying the substrate concentration from 0.05 to $30 \mathrm{mM}$ and calculated by Lineweaver-Burk equation. The substrate activity of the nitrilase RZ44 toward diverse nitriles with different structural specificity was considered. The relative activities for different nitrile substrates were determined by measuring the extent of ammonia released through the hydrolysis; the results of which are

Table 3. The effect of different carbon and ion sources on the bacterial growth and nitrilase production of $P$. aeruginosa RZ44

\begin{tabular}{lc}
\hline Compounds (1 mM) & Activity (\%) \\
\hline No Compound & 100 \\
$\mathrm{FeSO}_{4}$ & $107 \pm 2.1$ \\
$\mathrm{MgSO}_{4}$ & $110 \pm 3.2$ \\
$\mathrm{ZnSO}_{4}$ & $80 \pm 2.1$ \\
$\mathrm{MnSO}_{4}$ & $41 \pm 1.6$ \\
$\mathrm{CuSO}_{4}$ & $39 \pm 1.6$ \\
$\mathrm{ZnCl}_{2}$ & $76 \pm 1.3$ \\
$\mathrm{CoCl}_{2}$ & $16 \pm 0.2$ \\
$\mathrm{CaCl}_{2}$ & $12 \pm 0.1$ \\
$\mathrm{FeCl}_{3}$ & $52 \pm 2.2$ \\
$\mathrm{DTT}$ & $85 \pm 0.3$ \\
$\mathrm{EDTA}$ & $93 \pm 1.2$ \\
$\mathrm{H}_{2} \mathrm{O}_{2}$ & $27 \pm 1.7$ \\
\hline
\end{tabular}

Table 4. Substrate specificities of the RZ44 nitrilase. Nitrilase activity was measured in the presence of each substrate

\begin{tabular}{lc}
\hline Substrate & Activity (\%) \\
\hline Acetonitrile & 100 \\
Benzonitrile & $94 \pm 0.2$ \\
2-amino-benzonitrile & $88 \pm 1.1$ \\
Acrylonitrile & $107 \pm 0.8$ \\
Malononitrile & $44 \pm 0.8$ \\
Acetamide & $119 \pm 0.5$ \\
Acrylamide & $101 \pm 0.2$ \\
m-methyl-propionamide & $161 \pm 0.5$ \\
Bis acrylamide & $67 \pm 0.4$ \\
Benzamide & $257 \pm 0.8$ \\
pyridine & $23 \pm 0.7$ \\
3-Cyanopyridine & $102 \pm 0.8$ \\
\hline
\end{tabular}

listed in Table 4. Nitrilase RZ44 had very broad substrate specificity, hydrolyzing aliphatic, aromatic, and heterocyclic nitriles. There was a slight preference of the nitrilase RZ44 for aliphatic nitrile compounds as substrate (entries 1, 4, 5). A lower activity was also detected against aromatic nitriles (entries 2, 4, 11, 12). Amide substrates $(6-8,10,15)$ were also effectively metabolized by nitrilase RZ44. The maximum activity was detected against benzamide with almost 2.24 folds of enzymatic activity, but, nitrilase RZ44 showed a lower substrate hydrolysis activity in the presence of urea and glutamine (Table 4).

Biotransformation of the several nitriles by $P$. aeruginosa RZ44 resting cells is shown in figure 6 . These data were obtained by GC chromatography as described in the material and methods. The conversion data of the acetonitrile $(3.5 \mathrm{mM})$ and acrylonitrile $(5$ $\mathrm{mM}$ ) into the corresponding acid products by the $P$. aeruginosa RZ44 strain are shown in (Figure 6). Time course analysis of the nitrile conversion by the resting $P$. aeruginosa RZ44 cells showed that substrates (i.e. nitrile) was hydrolyzed within $8 \mathrm{~h}$.

\section{Discussion}

In this study, a nitrilase producing Pseudomonas aeruginosa was isolated and identified, which has potential for nitrile biotransformation. This strain produces a pink halo zone in the medium supplemented with $1 \%$ acetonitrile and phenol red.

From the perspective of the practical industrial application, the growth media strategy and reaction constraints are critical and need to be developed for the highest conversion of the nitriles (34). Consequently, we have examined the optimization of the different cultures condition that play a significant role in the enzyme pro- 
A

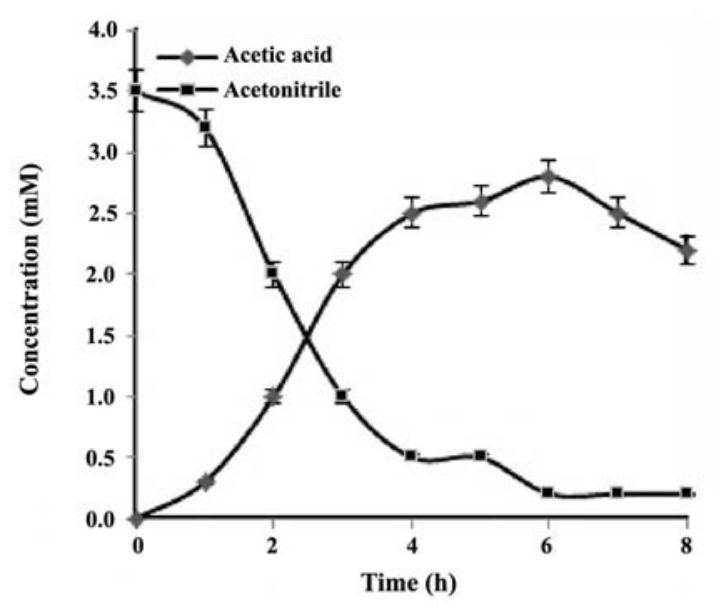

B

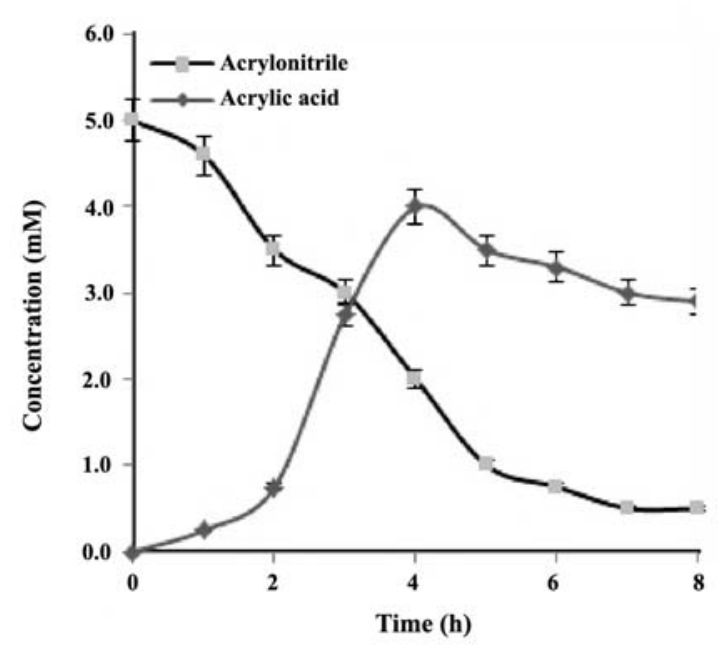

Figure 6. Conversion time on the biotransformation of the nitrile substrates. A: acetonitrile and B: acrylonitrile to the corresponding acid (acetic acid and acrylic acid), by P. aeruginosa RZ44. All experimental data are means \pm standard deviation (SD) of triplicate determinations

duction from $P$. aeruginosa RZ44. Results have indicated that glycerol has slightly decreased nitrilase production, while glucose and starch have strongly supported nitrilase production. Furthermore, results have shown that 5 g.L. $\mathrm{L}^{-1}$ of glucose and starch are the optimal concentration for nitrilase production. Our results agrees with what obtained for Rh. erythropolis ZJB-0910, for which sucrose induces lower nitrilase production than other carbon sources such as starch and glucose (33). But, it does not in agree with the Streptomyces sp. MTCC 7546. In spite of that, the results obtained through working on the culture medium that was carried out on Streptomyces sp. MTCC 7546 show that nitrilase production is not specific to a single carbon source (32). Our results also agree with the results reported by Zheng et al. that have shown 20 g.L $\mathrm{L}^{-1}$ glucose does properly affect the biomass and nitrilase production (37). In addition, Nageshwar and co-workers have also reported that A. faecalis MTCC 10757 nitrilase activity was maximal, when glucose was used as the carbon source. They have shown that 10 g.L $\mathrm{L}^{-1}$ is the optimal glucose concentration (34).

Results also have shown that 15 g.L. $\mathrm{L}^{-1}$ yeast extract and 5 g.L. $\mathrm{L}^{-1}$ urea are the optimum concentration of these two medium constituents for nitrilase production. Dong et al. have also reported that yeast extract and peptone are the preeminent nitrogen sources for nitrilase production by $R h$. erythropolis ZJB-0910 (33). They have also reported that biomass production by ZJB-0910 strain reduces with yeast extract at a concentration above 8 g.L $\mathrm{L}^{-1}$, in which nitrilase activity slightly improves (33).

The optimum $\mathrm{pH}$ for the production of nitrilase is 7.0 and therefore in subsequent studies the $\mathrm{pH}$ of the medium were adjusted to the 7.0 before sterilization. The nitrilase-producing media are recognized to favor enzyme synthesis mostly at the neutral $\mathrm{pH}(23,34,43)$. The optimal $\mathrm{pH}$ for nitrilase production was 7.0 by Streptomyces sp. MTCC 7546 (32). Nageshwar and co-workers have reported that the most promising $\mathrm{pH}$ for nitrilase production is between 7.0 and 7.5 by $A$. faecalis MTCC 10757 (34).

It was also shown that addition of $\mathrm{Mg}^{2+}, \mathrm{Fe}^{2+}$, and $\mathrm{Na}^{+}$supports the biomass in addition to nitrilase production. $\mathrm{Co}^{2+}, \mathrm{Mn}^{2+}$ and $\mathrm{Cu}^{2+}$ were confirmed to inhibit cell growth and enzyme activity. These results are in agreement with the results obtained for Rh. erythropolis ZJB-0910. Nitrilase production by Rh. erythropolis ZJB-0910 was slightly improved by $\mathrm{Mg}^{2+}$ and inhibited by $\mathrm{Ca}^{2+}, \mathrm{Cu}^{2+}$, and $\mathrm{Zn}^{2+}(33)$.

Results obtained on nitrilase characterization has also shown that, the enzyme exhibits high activity and stability comparatively at $\mathrm{pH} 7.0$, as its activity was drastically lost in the low and high $\mathrm{pH}$. According to these results, phosphate with $\mathrm{pH} 7.0$ was selected as the optimum buffer for the biotransformation experiments. The nitrilase-producing bacteria showed the best nitrilase activity in the $\mathrm{pH}$ range 7.0-8.0 $(23,34)$.

It is well known that the thermostability is an index of significant importance for nitrilase. The results obtained with respect to enzyme thermostabality have shown that the optimum temperature for the nitrilase activity and stability is $40^{\circ} \mathrm{C}$, as it gradually reduced. The optimal temperature of the nitrilase activity of Mesorhizobium sp. F28 was found to be around 37- 
$45^{\circ} \mathrm{C}$, but this enzyme was inactive at $55-65^{\circ} \mathrm{C}(44)$. Nageshwar and co-workers have reported that the optimal temperature for maximum activity would be between 20 and $30^{\circ} \mathrm{C}$ and the nitrilase activity was found to be maximum at $35^{\circ} \mathrm{C}$ by $A$. faecalis MTCC 10757 (34).

As well, RZ44 nitrilase was entirely repressed with $\mathrm{Co}^{+2}, \mathrm{Ca}^{+2}$, while the inhibition in the presence of $\mathrm{MnSO}_{4}$ and $\mathrm{CuSO}_{4}$ was about $60 \%$. This enzyme activity was slightly increased in the presence of $\mathrm{Fe}^{+2}$ and $\mathrm{Mg}^{+2}$. Nocardia sp. NCIB 11216 nitrilase was also repressed by $\mathrm{Fe}^{+3}$ and $\mathrm{Mn}^{+2}$. Hydrogen peroxide reduced the nitrilase activity of RZ44 by about $70 \%$. Feng and coworkers reported that, Mesorhizobium sp. F28 was sensitive to $\mathrm{CuSO}_{4}, \mathrm{Ag}_{2} \mathrm{SO}_{3}$, which are sulfhydryl containing salts. This research has implied that the nitrilase active site of the Rh. erythropolis N04 is consisted of cysteine and serine, since the nitrilase was repressed to a significant degree by several sulfhydryl and oxidizing elements. Consequently, the nitrilase active site of these strains might contain cysteine and serine residues (44).

The chelating agent such as EDTA had diverse effects on the nitrilase activity of the bacteria. EDTA was shown to have no major effect on the activity of $P$. aeruginosa RZ44 nitrilase. This finding is in agreement with the nitrilase of $R$. rhodochrous $\mathrm{J} 1$ and $B$. pallidus Dac521, which are unaffected by $1 \mathrm{mM}$ and 10 mM EDTA, respectively $(17,19)$. Mesorhizobium sp. F28 nitrlase was diminished about $64 \%$ by EDTA (44).

Additionally, the reducing agents such as beta-mercaptoethanol and DTT have no major effect on the nitrilase activity of $P$. aeruginosa RZ44, as observed in R. rhodochrous J1 (17), B. smithii SC-J05-1 (45), B. pallidus Dac521 (19) and Mesorhizobium sp. F28 (44).

$K \mathrm{~m}$ value has indicated that acetonitrile was noticeably the preferred substrate for RZ44 nitrilase when compared with the acetamide. But, the specific activity of RZ44 nitrilase for acetamide was 2 times more than that of acetonitrile. The specific activity of RZ44 nitrilase was about 616 and 1383 U.mg- $^{-1}$ for acetonitrile and acetamide, respectively. The specific activities for $R$. rhodochrous $\mathrm{J} 1$ (115 U.mg-1 dcw) (17), $R$. pyridinovorans MW3 (97 U.mg-1 dcw) (46), B. imperialis CBS 498-74 (47 U.mg-1 dcw) (47), and $R$. rhodochrous PA-34 (55.0 U.mg-1 dcw) (25) have been reported. These results indicated that RZ44 has high substrate tolerance and higher nitrilase activity.

RZ44 nitrilase shows a broad substrate specificity, hydrolyzing the aliphatic, aromatic, and heterocyclic nitriles. However, it was found a slight preference for
RZ44 nitrilase toward aliphatic as nitriles as substrate (entries 1, 4, 5). A lower RZ44 nitrilase activity was also detected toward aromatic nitriles (entries 2, 4, 11, 12). Amide substrates $(6-8,10,15)$ were also effectively metabolized by RZ44 nitrilase. The maximum activity was detected with benzamide about 2.24 folds, but, RZ44 nitrilase show lower substrate hydrolyzing activity in the presence of urea and glutamine. Similarly, the nitrilases produced by Bacillus pallidus (19), $R$. rhodochrous K22 (43), Bacillus subtilis ZJB-063 (37), Nocardia globerula NHN-2 (20) and Amycolatopsis sp. IITR215 (48), show a broad substrates, as they hydrolyze aliphatic, aromatic and heterocyclic nitriles.

Biotransformation assessment by GC chromatography also confirms that the $P$. aeruginosa RZ44 resting cells directly hydrolyze nitrile substrate to the corresponding acid, similar to that of $R h$. rhodochrous $\mathrm{K} 22$ (43) and A. faecalis (IICT-A3) (34).

It was also revealed that the quantity of acrylic acid and acetic acid identified from the conversion of the correspond nitrile is maximum after 4 and 6 hours of incubation with acrylonitrile and acetonitrile, respectively. The time course of acetonitrile $(3.5 \mathrm{mM})$ and acrylonitrile $(5 \mathrm{mM})$ conversion into their corresponding acids by $B$. cereus FA12 resting cells showed that these nitriles were hydrolyzed within $12 \mathrm{~h}$, and the amount of ammonia produced from acetamide and acetonitrile was maximum after 5 and 7 hours of the incubation, respectively (41). Remarkably, the quantity of the acetic and acrylic acids identified from the conversion of acetonitrile and acrylonitrile showed a small aberration from the theoretical quantity which was equivalent to the quantity of acetonitrile and acrylonitrile added ( 3.5 and $5 \mathrm{mM}$, respectively). This observation has exhibited that the amide or acid was partially converted by $P$. aeruginosa RZ44. In addition, an increased quantity of acid was used with the increase in conversion time.

\section{Conclusions}

$P$. aeruginosa RZ44 is a strain which was isolated from the sewage of the city of Kerman. $P$. aeruginosa RZ44 nitrilase shows broad substrate specificity for hydrolysis of the aliphatic, aromatic, and heterocyclic nitriles. Medium optimization showed that some environmental conditions play significant role in the nitrilase production from $P$. aeruginosa strain RZ44. The maximum nitrilase production was detected in the presence of glucose, yeast extract, and $\mathrm{Mg}^{+2}$ following to $24 \mathrm{~h}$ of incubation. It was mentioned that, using resting cells as catalyst, there is no need for an additional immobilization of the catalyst before use, and it would diminish the 
cost of production to a large amount and saving of the time, as well. Results have indicated that $P$. aeruginosa strain RZ44 has an excellent nitrile conversion capacity, which can be used for nitrile biotransformation.

\section{Acknowledgements}

The authors express their gratitude to the Research Council of the Shahid Bahonar University of Kerman and Iran National Science Foundation (INSF) for their financial support during the course of this project.

\section{References}

1. Banerjee A, Sharma R, Banerjee U. The nitrile-degrading enzymes: current status and future prospects. Appl Microbiol Biotechnol. 2002;60 (1-2):33-44. DOI: 10.1007/s00253-0021062-0

2. Banerjee A, Kaul P, Sharma R, Banerjee UC. A high-throughputamenable colorimetric assay for enantioselective screening ofnitrilase producing microorganisms. J Biomol Screen. 2003;8:559-565. DOI: 10.1177/1087057103256910

3. He YC, Xu JH, Xu Y, Ouyang LM, Pan J. Biocatalyticsynthesis of (R)-mandelic acid from racemic mandelonitrile by anewly isolated nitrilase-producer Alcaligenes sp. ECU0401. Chin Chem Lett. 2007;18(6):677-680. DOI: 10.1016/j.cclet.2007. 04.034

4. Kiziak C, Stolz A. Identification of amino acid residues responsible for the enantioselectivity and amide formation capacity of the arylaceto nitrilase from Pseudomonas fluorescens EBC191. Appl Environ Microbiol. 2009;75:55925599. DOI: 10.1128/AEM.00301-09

5. Ma YC, Yu HM, Pan WY, Liu CC, Zhang SL, Shen ZY. Identification of nitrile hydratase-producing Rhodococcus ruber TH and characterization of an amiE-negative mutant. Bioresour Technol.2010;101:285-291. DOI: 10.1016/j. biortech.2009.07.057

6. Ma DY, Wang DX, Pan J, Huang ZT, Wang MX. Nitrile biotransformations for the synthesis of enantiomerically enriched $\beta 2-$, and $\beta 3$-hydroxy and -alkoxy acids and amides, a dramatic O-substituent effect of the substrates on enantioselectivity. Tetrahedron Asymmetr. 2008;19(3):322-329. DOI: 10.1016/j. tetasy.2008.01.017

7. Johannsen FR, Levinskas GJ, Berteau PE, Rodwell DE. Evaluation of the teratogenic potential of three aliphatic nitriles in the rat. Fundam Appl Toxicol. 1986;7(1):33-40. DOI: $10.1093 /$ toxsci/7.1.33

8. He YC, Xu JH, Su JH, Zhou L. Bioproduction of glycolic acid from glycolonitrile with a new bacterial isolate of Alcaligenes sp. ECU0401. Appl Biochem Biotechnol.2010;165(5):14281440. DOI: 10.1007/s12010-009-8607-y

9. Bhalla T, Miura A, Wakamoto A. Asymmetric hydrolysis of aaminonitriles to optically active amino acids by a nitrilase of Rhodococcus rhodochrous Pa-34. Appl Microbiol Biotechnol. 1992;37:184-190. DOI: 10.1007/BF00178168

10. Bianchi D, Bosetti A, Cesti P, Franzosi G, Spezia. Stereoselective microbial hydrolysis of 2-aryloxypropionitriles. Biotechnol Lett. 1991;13:241-244. DOI: 10.1007/ BF01041477
11. Trott S, Bauer R, Knackmuss HJ, Stolz A. Genetic and biochemical characterization of an enantio selective amidase from Agrobacterium tumifaciens strain d3. Microbiol. 2001;147:1815-1824. DOI: 10.1099/00221287-147-7-1815

12. Zhu DM, Mukherjee C, Yang Y, Rios BE, Gallagher DT, Smith NN, Biehl ER, Hua L. A new nitrilase from Bradyrhizobium japonicum USDA110: Gene cloning, biochemical characterizationand substrate specificity. J Biotechnol. 2008;133(3): 327333. DOI: 10.1016/j.jbiotec. 2007.10.001

13. Kumar S, Mohan U, Kamble AL, Pawar S, Banerjee UC. Cross-linked enzyme aggregates of recombinant Pseudomonas putida nitrilase for enantioselective nitrile hydrolysis. Bioresour Technol. 2010;101:6856-6858. DOI: 10.1016/j.biortech.2010.03.084

14. Mei S, Zheng YG, Shen YC. Isolation and characterization of a novel Arthrobacter nitroguajacolicus ZjutB06-99, Capable of converting acrylonitrile to acrylic acid. Process Biochem. 2009;44:781-785. DOI: 10.1016/j.procbio.2009.03.006

15. Chand D, Kumar H, Sankhian UD, Kumar D, Vitzthum F, Bhalla TC. Treatment of simulated wastewater containing toxic amides by immobilized Rhodococcus rhodochrous NHB-2 using a highly compact 5-stage plug flow reactor. World J Microbiol Biotechnol. 2004;20(7):679-686. DOI: 10.1007/s11274-004-2158-8

16. Prasad S, Sharma DR, Bhalla TC Nitrile- and amidehydrolysing activity in Kluyveromyces thermotolerans MGBY 37. World J Microbiol Biotechnol. 2005;21:14471450. DOI: $10.1007 / \mathrm{s} 11274-005-6563-4$

17. Kobayashi M, Komeda H, Nagasawa T, Yamada H, Shimizu $\mathrm{S}$. Occurrence of amidase in the industrial microbe, Rhodococcus rhodochrous J1. Biosci Biotechnol Biochem. 1993;57:1949-1950. DOI: 10.1271/bbb.57.1949

18. Gilligan T, Yamada H, Nagasawa T. Production of S- (+)-2phenylpropionic acid from (R,S)-2-phenylpropionitrile by the combination of Nitrile hydratase and stereoselective amides in Rhodococcus equi TG328. Appl Microbiol Biotechnol. 1993;39:720-725. DOI: 10.1007/BF00164456

19. Cramp R, Gilmour M, Cowan DA. Novel thermophilic bacteria producing nitrile-degrading enzymes. Microbiology. 1997;143:2313-2320. DOI: 10.1099/00221287-143-7-2313

20. Bhalla TC, Kumar H. Nocardia globerula NHB-2: a versatile nitrile-degrading organism. Can J Microbiol. 2005;51(8):705708. DOI: 10.1139/w05-046

21. Jin LQ, Liu ZQ, Zheng YG, Shen YC. Identification and characterization of Serratia marcescens ZJB-09104, a nitrile-converting bacterium. World J Microbiol Biotechnol. 2010;26:817-823. DOI: 10.1007/s11274-009-0238-5

22. Komeda H, Harada H, Washika S, Sakamoto T, Ueda M, Asano Y. A novel R-stereo selective amidase from Pseudomonas sp. MCI3434 acting on piperazin-2-tertbutylcarboxamide. Eur J Biochem. 2004;271:1580-1590. DOI: $10.1111 /$ j.1432-1033

23. Kim JS, Tiwari MK, Moon HJ, Jeya M, Ramu T, Oh DK, Kim IW, Lee JK. Identification and characterization of a novel nitrilase from Pseudomonas fluorescens Pf-5. Appl Microbiol Biotechnol. 2009;83:273-283. DOI: 10.1007/s00253-0091862-6

24. Makhongela HS, Glowacka AE, Agarkar VB, Sewell BT, 
Weber B, Cameron RA, Cowan DA, Burton SG. A novel thermostable nitrilase superfamily amidase from Geobacillus pallidus showing acyl transfer activity. Appl Microbiol Biotechnol. 2007;75:801-811. DOI: 10.1007/s00253-0070883-2

25. Prasad S, Raj J, Bhalla TC (2009). Purification of a hyperactive nitrile hydratase from resting cells Rhodococcus rhodochrous PA-34. Indian J Microbiol. 2009;49(3):237-242. DOI: 10.1007/s12088-009-0033-x

26. Kaur G, Soni P, Tewari R, Sharma R. Isolation and Characterization of a Nitrile-Hydrolysing Bacterium Isoptericola variabilis RGT01. Indian $J$ Microbiol. 2014;54(2):232-238. DOI: 10.1007/s12088-014-0453-0

27. Santoshkumar M, Anand S, Nayak O, Timmanagouda A, Karegoudar B. A plate method for screening of bacteria capable of degrading aliphatic nitriles. J Ind Microbiol Biotechnol. 2010;37:111-115. DOI: 10.1007/s10295-009-0663-3

28. Sambrook J, Russell D. Molecular Cloning: A Laboratory Manual, Cold Spring Harbor, New York. 2001. DOI:10.1002/abio.37005011848.

29. Badoei-Dalfard A, Karami Z. Screening and isolation of an organic solvent tolerant-protease from Bacillus sp. JER02: Activity optimization by response surface methodology. $J$ Mol Catal B: Enz. 2013;89:15-23. DOI: 10.1016/j.molcatb.2012.11.016

30. Tamura K, Dudley J, Nei M, Kumar S. MEGA4: Molecular Evolutionary Genetics Analysis (MEGA) software version 4.0. Mol Bio Evol. 2007;24:1596-1599. DOI: 10.1093/molbev/msm092

31. Fawcett JK, Scott JE. A rapid and precise method for the determination of urea. J Clin Pathol. 1960;13:156-159. DOI: 10.1136/jcp.13.2.156

32. Khandelwal AK, Nigam VK, Choudhury B, Mohan MK and Ghosh P. Optimization of nitrilase production from a new thermophilic isolate. $J$ Chem Technol Biotechnol. 2007;82:646-651. DOI: 10.1002/jctb.1721

33. Dong HP, Liu ZQ, Zheng YG, Shen YC. Medium optimization for nitrilase production by newly isolated Rhodococcus erythropolis ZJB-0910 using statistical designs. Chem Biochem Eng Q. 2011;25(3):351-358.

34. Nageshwar YV, Sheelu G, Shambhu RR, Muluka H, Mehdi N, Malik MS, Kamal A. Optimization of nitrilase production from Alcaligenes faecalis MTCC 10757 (IICT-A3): effect of inducers on substrate specificity. Bioprocess Biosyst Eng. 2011;34:515-523. DOI: 10.1007/s00449-010-0500-0

35. Zhang Z, Gao L, Zhao C, Qiu J. Nitrile- and amide-hydrolysing activity of acrylic acid-tolerant yeast Trichosporon asahii ZZB-1. Ann Microbiol. 2011;62 (2):615-622. DOI: 10.1007/ s13213-0110298-2

36. Badoei-Dalfard A, Karami Z, Ravan H. Purification and characterization of a thermo- and organic solvent-tolerant alkaline protease from Bacillus sp. JER02. Prep Biochem Biotech. 2015;45(2):128-143. DOI: 10.1080/10826068.2014.907176. Process Biochem. 2008;43:1391-1397. DOI: 10.1016/j. procbio.2008.08.009
37. Zheng YG, Chen J, Liu ZQ, Wu MH, Xing LY, Shen YC. Isolation, identification and characterization of Bacillus subtilis ZJB-063, a versatile nitrile-converting bacterium. Appl

38. Microbiol Biotechnol. 2008;77:985-993. DOI: 10.1007/s 00253-007-1236-x

Heald SC, Brandão PFB, Hardicre R, Bull AT. Physiology, biochemistry and taxonomy of deep-sea nitrile metabolizing Rhodococcus strains. Antonie van Leeuwenhoek. 2001; 80:169-183.

39. Jin LQ, Liu ZQ, Xu JM, Zheng YG. Biosynthesis of nicotinic acid from 3-cyanopyridine by a newly isolated Fusarium proliferatum ZJB-09150. World J Microbiol Biotechnol. 2013;29:431-440. DOI: 10.1007/s11274-012-1195-y

40. Brenner DJ, Krieg NR, Staley JT, Garrity GM. Bergey's Manual of Systematic Bacteriology, 2nd ed., vol. 2, parts A, B and C, Springer-Verlag, New York, NY.2005.

41. Ramezani-pour N, Badoei-Dalfard A, Namaki-Shoushtari A,

Karami Z. Nitrile-metabolizing potential of Bacillus cereus strain FA12; Nitrilase production, purification, and character-

ization. Biocatal Biotransfor. 2015;33:156-166. DOI: 10.3109/10242422.2015.1083015

42. Banerjee A, Kaul P, Banerjee UC. Purification and characterization of an enantioselective arylacetonitrilase from Pseudomonas putida. Arch Microbiol. 2006;184:407-418. DOI: 10.1007/s00203-005-0061-9

43. Kobayashi M, Yanaka N, Nagasawa T, Yamada H. Monohydrolysis of an aliphatic dinitrile compound by nitrilase from Rhodococcus rhodochrous K22. Tetrahedron. 1990;46:5587-5590. DOI: 10.1016/S0040-4020(01)87757-7

44. Feng YS, Chen PC, Wen FS, Hsiao WY, Lee CM. Nitrile hydratase from Mesorhizobium sp. F28 and its potential for nitrile Biotransformation 43. Kobayashi M, Yanaka N, Nagasawa T, Yamada H. Monohydrolysis of an aliphatic dinitrile compound by nitrilase from Rhodococcus rhodochrous K22. Tetrahedron. 1990;46:5587-5590. DOI: 10.1016/S00404020(01)87757-7

45. Takashima Y, Yamaga Y, Mitsuda S Nitrile hydratase from a thermophilic Bacillus smithii. J Ind Microbiol Biotechnol. 1998;20:220-226. DOI: 10.1038/sj.jim.2900514

46. Precigou S, Wieser M, Pommares P, Goulas P, Duran R.

Rhodococcus pyridinovorans MW3, a bacterium producing a nitrile hydratase. Biotechnol Lett. 2004;26:1379-1384. DOI: 10.1023/B:BILE.0000045636.47527.99

47. Cantarella M, Spera A, Leonetti P, Alfani F. Influence of initial glucose concentration on nitrile hydratase production in Brevibacterium imperialis CBS 498-74. J Mol Catal B: Enz. 2002;20:405-414. DOI: 10.1016/S1381-1177(02)00192-3

48. Babu V, Choudhury BS. Nitrile-metabolizing potential of Amycolatopsis sp. IITR215. Process Biochem. 2010;45(6): 866-873. DOI: 10.1016/j.procbio.2010.02.008 